is considerable. It is comparable with the loss incurred by sterilizing the potato at $p \mathrm{H} 9$ instead of $p H \mathbf{H} \cdot 4$, as is shown in the table.

It would appear that the greater part of the vitamin is washed out into the medium in the process of steaming. These figures afford an additional argument in favour of always cooking potatoes in their skins.

Department of Soil Microbiology, JANE MEIKLEJOHN.

Rothamsted Experimental Station, Harpenden.

${ }^{1}$ Schopfer, W. H., and Jung, A., C.R.V' . Cong. int. Tech. Chem. Indust. Agric. Schéveningue, 22 (1937).

${ }^{2}$ Pyke, M. A., J. Soc. Chem. Ind., 58, 338T (1939).

\section{Effect of Hexœstrol and of Alpha Methyl Stilbene on the Insulin Content of the Pancreas of the Rabbit}

Considerable evidence accumulated during the past two years shows that administration of natural and synthetic cestrogens increases the amount of insulin in the pancreas of the rat t.2,3,4. $^{1,2}$

Further experiments on the action of the synthetic œestrogen hexœestrol, $4: 4^{\prime}$ dihydroxy - $\alpha$, $\beta$ - diethyldihydrostilbene, on the insulin content of the pancreas of the rabbit have been carried out in this laboratory. Some experiments using $\alpha$ methyl stilbene, of which Dodds, Fitzgerald, and Lawson ${ }^{5}$ have found that even very large doses are non-ostrogenic, have also been carried out. The.results are summarized in the following table.

The two substances were dissolved in arachis oil and injected intramuscularly, over periods of 410 weeks.

\section{A Census of Atmospheric Pollen}

THE pollen content of the atmosphere is of interest in relation to general plant biology, the pollen analysis of peats and the study of allergic diseases such as hay fever and asthma. This subject was first investigated by Blackley ${ }^{1}$ in Great Britain and has since been pursued on a wide scale in the United States ${ }^{2}$. So far as is known to us, however, it has received attention from only a very few workers on the Continent of Europe ${ }^{3,4,5}$ and no such researches made in Great Britain (other than Blackley's) have been published.

We have recently completed a continuous investigation of the day-to-day changes during twelve months in the pollen rain at Llandough Hospital, Cardiff. Microslides previously coated with glycerine-gelatine containing fuchsin as described by Wodehouse ${ }^{6}$ have been exposed, one every twenty-four hours, in a horizontal position under conditions which allowed reasonably free passage of air over them while affording protection from rain. Each slide was then mounted and all pollen grains under a $\frac{7}{8}$ in. coverslip were identified so far as possible and counted.

The effective pollen season was found to extend from the middle of February to the end of October and to fall into three main phases, dominated by trees, grasses and herbaceous dicotyledons respectively. Of the trees, birch (Betula) gave by far the highest pollen count, 315 (63 per sq. cm.) on April 28-29, and yew (Taxus) gave the next highest, 142 (28 per sq. cm.) on March 26-27. Oak (Quercus) had a medium value, 92 (18 per sq. cm.) on May 16-17, as did elm (Ulmus), 83 (17 per sq. cm.) on March 27-28, and hazel (Corylus), 63 (13 per sq. cm.) on March 20-21, while alder (Alnus), 29 (6 per sq. cm.) on March 25-26, was rela-

TABLE 1 .

\begin{tabular}{|c|c|c|c|c|c|c|c|c|}
\hline \multirow{2}{*}{$\begin{array}{l}\text { Number } \\
\text { of rabbits }\end{array}$} & \multirow{2}{*}{$\begin{array}{c}\text { Substance } \\
\text { injected and } \\
\text { average } \\
\text { total dose }\end{array}$} & \multicolumn{2}{|c|}{$\begin{array}{l}\text { Body weight } \\
\text { grams }\end{array}$} & \multirow{2}{*}{$\begin{array}{l}\text { Blood } \\
\text { sugar } \\
\text { mgm. } \%\end{array}$} & \multirow{2}{*}{$\begin{array}{l}\text { Liver } \\
\text { wt. } \\
\text { grams }\end{array}$} & \multirow{2}{*}{$\begin{array}{l}\text { Testis } \\
\text { wt. (2) } \\
\text { grams }\end{array}$} & \multirow{2}{*}{$\begin{array}{l}\text { Adrenal } \\
\text { wt. (2) } \\
\text { grams }\end{array}$} & \multirow{2}{*}{$\begin{array}{c}\text { Insulin } \\
\text { content in } \\
\text { units gram } \\
\text { of pancreas }\end{array}$} \\
\hline & & Init. & Final & & & & & \\
\hline 5 (1 female) & $=$ & - & 2,215 & 102 & $53 \cdot 0$ & $4 \cdot 28$ & 0.32 & $5 \cdot 20$ \\
\hline 5 (1 female) & $40 \mathrm{mgm}$. hexœstrol & 2,386 & 2,306 & 98 & $44 \cdot 2$ & 1.27 & 0.31 & 8.85 \\
\hline 3 & $\begin{array}{l}320 \mathrm{mgm} \text {. of } \\
\text { a methyl stilbene }\end{array}$ & 2,190 & 2,323 & 84 & $66 \cdot 0$ & $4 \cdot 35$ & 0.47 & $24 \cdot 49$ \\
\hline
\end{tabular}

From this table it is seen that the hexœstrol brings about atrophy of the testes and a moderate increase in the amount of pancreatic insulin. $\alpha$ methyl stilbene, on the other hand, increases the amount of pancreatic insulin to a marked degree, but has no effect on the testis weight, which result substantiates the finding of Dodds, Fitzgerald and Lawson that it is nonœstrogenic.

This report will be published shortly in the Proceedings of the Linnean Society of New South Wales.

I wish to take the opportunity of acknowledging my indebtedness to the Society for a scholarship grant, and to Prof. C. G. Lambie for his interest in this work.

Department of Medicine, Mervyn Griffriths.

University of Sydney.

"Giriffiths, M., and Young, F. G., NATURE, 146, 266 (1940).

2 Marks, H. P., and Young, F. G., Lancet, 239, 710 (1940).

- Griffiths, M., Marks, H. P., and Young, F. G., NATURe, 147, 359 (1941) -Conrat, H. L. F., Herring, V. V., Simpson, M. F., and Evans, H. M.,
Proc. Soc., Exp., Biol. and Med., 48, 333 (1941). ${ }^{5}$ Dodds, E. C., Fitzgerald, M. E. H., and Lawson, W., NATURE, 140, tively low and ash (Fraxinus), 12 (2 per sq. cm.) on April 11-12, was very low.

The grass pollen, from being negligible at the beginning of June, reached 386 (77 per sq. cm.) on June 11-12 and a maximum of 482 (96 per sq. cm.) on June 22-23. It was still 395 (79 per sq. cm.) on July 5-6, but toward the end of this month the number fell rapidly.

The phase of herbaceous dicotyledons, including chiefly the genera Urtica, Plantago and Artemisia and the family Umbelliferæ, gave low values only: Urtica 27 (5 per sq. cm.) on August 27-28 and 10 (2 per sq. cm.) on September 6-7, Umbelliferæ 10 (2 per sq. em.) on August 27--28, Plantago 5 (1 per sq. cm.), and Artemisia 12 (2 per sq. em.) both on August 20-21, while 10 grains (2 per sq. cm.) of the Compositæ-(Aster type)-were found on October 4-5. Pollen of some of these genera was found in larger quantities, however, during the grass season, namely, Urtica 58 (12 per sq. cm.) on June 19-20, Plantago 28 (6 per sq. cm.) on June 6-7 and Umbelliferæ 24 (5 per sq. cm.) on May 27-28.

Certain entomophilous pollens appeared in sur- 